\title{
密なセレイティッドフィン付き千鳥配列円管群からの渦放出*
}

$$
\begin{aligned}
& \text { 濱 川 洋 充*1, 村 岡 功 } \text { *2 }^{* 2} \\
& \text { 西 田 英 一*3, 深 野 徹*4 }
\end{aligned}
$$

\section{Vortex Shedding from Staggered Tube Banks with Closely Mounted Serrated Fin}

\author{
Hiromitsu HAMAKAWA ${ }^{* 5}$, Kouichi MURAOKA, \\ Eiichi NISHIDA and Tohru FUKANO \\ *5 Department of Mechanical Engineering, Oita University, \\ 700 Dannoharu, Oita-shi, Oita, 870-1192 Japan
}

\begin{abstract}
In the present paper the attention is focused on the vortex shedding from the tube banks with closely mounted twist serrated fin. The tube banks were installed rigidly in the test section of the wind tunnel. We measured the mean velocity, the spectrum of velocity fluctuation and the gap velocity in the simulated tube banks which has same pitch ratio as that of a boiler heat exchanger. We found two types of vortex shedding with different Strouhal number of 0.40 and 0.20 in the case of Reynolds number $R_{e}$, based on the equivalent diameter and gap velocity, between $2.8 \times 10^{4}$ and $6.2 \times 10^{4}$. Strouhal numbers $S_{t}$ were calculated by using the measured values of vortex shedding frequency, gap velocity and the equivalent diameter. The vortex shedding of $S_{t}=0.40$ mainly formed within the fin-tube banks and the other vortex of $S_{t}=0.20$ was in the wake of the fin-tube banks. Strouhal number of vortex shedding inside the fin-tube banks changed from 0.40 to 0.32 over $R_{e}=$ $6.2 \times 10^{4}$. The applicability of the equivalent diameter obtained by a single circular cylinder with serrated fin to the fin-tube banks was examined. Strouhal number 0.32 agreed with Strouhal number 0.30 obtained from Fitz-hugh's map for bare tube banks and other Strouhal number of 0.20 is similar to the vortex shedding from a circular cylinder.
\end{abstract}

Key Words : Vortex, Equivalent Diameter, Strouhal Number, Serrated Fin, Staggered Tube Banks, Flow Induced Vibration, Boiler

\section{1. 緒 言}

管に直交してガスが流れる管式の熱交換器では, 気柱共鳴現象が発生し，大騒音や振動が問題となる ことがある。この現象が発生するとその防止対策に 多大な費用と時間が必要となるため，設計段階でこ れを予知し防止する必要がある。

気柱共鳴騒音は，管群からの渦放出による気流音 と熱交換器を構成するダクトが共鳴して発生すると 考えられている(1)〜而。管群から放出される渦の周波 数と種々の管配列の関係は，ストローハル数のマッ プとして Y.N. Chen ${ }^{(5)}$, J.S. Fitz-hugh ${ }^{(8)}$, A. Zukauskas $\zeta^{(9)}$, D. S. Weaver $5^{(10)}$, A. Oengören ら ${ }^{(11)}$ などが 明らかにしており，実機ボイラの熱交換器の設計時 に渦放出周波数を見積もるために使用されている.

*. 原稿受付 2008 年 12 月 11 日.

*1 正員, 大分大学工学部 (画870-1192 大分市旦野原 700).

*2 (株) 高田工業所(画 806-8567 北九州市八幡西区築地町 1-1).

*3 正員, 湘南工科大学機械システム工学科(《251-8511 藤沢 市辻堂西海岸 1-1-25).

*4 正員, フェロー, 九州大学(画 819-0395 福岡市西区元岡 744).

E-mail : hamakawa@cc.oita-u.ac.jp
ところで近年，排熱回収用ボイラ等では熱交換器 のガス側の熱伝達特性を向上させるために，伝熱管 の表面にフィンが設置されている，鈴木ら ${ }^{(12)}$, 根本 $ら^{(13) \sim(15)}$ はこのようなフィン付きの伝熱管群におい ても気柱共鳴䮎音が発生することを明らかにした。 フィン付き単管および管群からの渦放出特性につい ては, Y. N. Chen ${ }^{(5)}$, W. A. Mair ${ }^{(16)}$, J. Kouba ${ }^{(17)}$, 川口 と奥井 ${ }^{(18) \sim(20)}$, 廣田 ${ }^{(21)}$, S. Ziada $ら^{(22)}$, 濱川ら ${ }^{(23)}$ の研究がある.これらの結果から，伝熱管表面にフ インを設置するとフィンの無い裸管に比べ渦放出特 性が変化し, 設計時の渦放出周波数の見積もりに裸 管におけるストローハル数のマップが使用できない ことがわかった，そこで，著者らは渦放出に関しフ イン付き管を等価な円柱直径に置き換え, 従来の設 計ツールをそのまま利用できるような設計手法を提 案し(24)，ピッチが $5.08 \mathrm{~mm}$ のツイストセレイティッ ドフィン付き管群においてその効果を検証した(25). しかしながら，川ロら (18)〜(20)はフィン付き管群にお いてフィンのスパン方向のピッチが渦発生特性に影 響することを明らかにしており，ピッチが $5.08 \mathrm{~mm}$ 
とは異なる場合にも本設計法が有効であるかどうか は末だ不明である。

本研究では，フィンのピッチが小さい $3.63 \mathrm{~mm}$ のツイ ストセレイティッドフィン付き千鳥配列管群からの洞放 出特性を実験的に明らかにするとともに，本ピッチのフ イン付き管群において，裸管管群のストローハレ数のマ ップと等価直径 ${ }^{(24)}$ を用いた渦放出周波数の予測手法が有 効であるか否かを検討した。

\section{2. おもな記号}

$A$ ：熱線出力 $[\mathrm{mV}]$

$D$ ：管直径 $[\mathrm{mm}]$

$D_{f}$ ：フィン外径 $[\mathrm{mm}]$

$D^{*}$ : フィン付き管の等価直径 [mm]

$E$ ： パワースペクトルの振幅值の無次元值

$E_{p o} ：$ パワースペクトルのピーク周波数か

ら $\pm 5 \mathrm{~Hz}$ の周波数帯域のパーシャル オーバオール值

$f$ : 周波数 $[\mathrm{Hz}]$

$f_{p}:$ スペクトルのピーク周波数 $[\mathrm{Hz}]$

$L$ : 抗力方向の管中心間距離 $[\mathrm{mm}]$

$R_{e}$ : レイノルズ数 $\left(=U_{g} D^{*} / v, U_{\infty} D / v\right)$

$S_{t} \quad: \quad$ ストローハル数 $\left(=f_{p} D^{*} / U_{g}, f_{p} D / U_{g}\right)$

$t \quad:$ 時間 [s]

$T$ ：揚力方向の管中心間距離 $[\mathrm{mm}]$

$t_{h} \quad$ : フィンの厚さ $[\mathrm{mm}]$

$u^{\prime}$ ： 速度変動強さ

$U_{g} \quad: \quad$ ギャップ流速 $[\mathrm{m} / \mathrm{s}]$

$U_{\infty}$ : 主流速度 $[\mathrm{m} / \mathrm{s}]$

$X$ : 流れ方向距離 $[\mathrm{mm}]$

$Y \quad$ ：流れ方向之直角方向の距離 [mm]

$Y_{p} \quad$ : フィンのスパン方向ピッチ $[\mathrm{mm}]$

$v$ : 動粘性係数 $\left[\mathrm{m}^{2} / \mathrm{s}\right]$

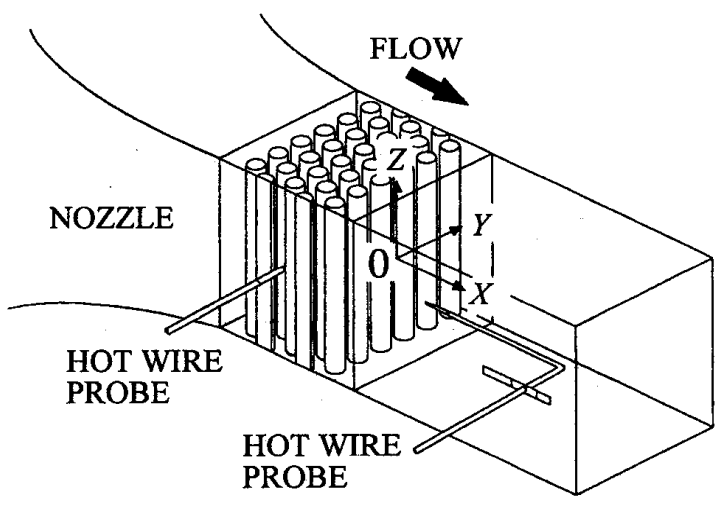

Fig. 1 Experimental apparatus

\section{3. 実験装置および方法}

測定部概要を図 1 に示す. 測定部断面が 500mm $\times$ $500 \mathrm{~mm}$ の吹出式風洞のノズル出口から $130 \mathrm{~mm}$ 下流 に供試体であるフィン付き管群をテストセクション の下壁面に垂直に固定し設置した，風洞出口におけ る一様流の速度は熱交換器の実機条件を考慮して 4.3 $14.2 \mathrm{~m} / \mathrm{s}$ の範囲で変化させた. この一様流の速 度を代表速度とし, 代表寸法として管直径 $D$ を用い たレイノルズ数はそれぞれ $R_{e}=0.9 \times 10^{4} \sim 3.0 \times 10^{4}$ で ある. 管群上流の流れの乱れは $15.5 \mathrm{~m} / \mathrm{s}$ のとき約 $0.5 \%$ である. 管群後方のダクトの長さは最下流側の 管 (以下, 最後列管と称す) $の$ 中心から下流へ約 $20 D_{f}$ $\left(D_{f}=57.2 \mathrm{~mm}\right)$ である.

管群の主要寸法と管群の配列を図 2 に示す. 揚力 方向 $(Y$ 方向) のピッチ $T$ が $82 \mathrm{~mm}$, 抗力方向 $(X$ 方向)のピッチ $P$ が $71 \mathrm{~mm}$ の千鳥配列の管群である. ダクトの幅は $500 \mathrm{~mm}$ であり, 壁面上では半割にし たフィン付き管を取り付けて流れ場に及ぼす壁面の 影響を減らしている。

実験に使用した供試モデルは実際の熱交換器にて使用 されている代表的な仕様て作成したものであり，その概 要を図 3 に示す. 直径 $D=31.8 \mathrm{~mm}$ の円管表面にフィンと して高さ $12.7 \mathrm{~mm}$ ，厚さ $t_{h}=12 \mathrm{~mm}$ の帯状の薄板力螺解状 に巻力氺ており，この帯状の薄板に幅 $2 \mathrm{~mm}$, 深さ $7 \mathrm{~mm}$ の切れ込みが入り，それに若下ひねりが加えられた針状 のツイストセレイティッドフィン(2324)が設置されている. フィン外径 $D_{f}$ は $572 \mathrm{~mm}$ ，フィンのピツチ $Y_{p}$ は $3.63 \mathrm{~mm}$ である.このセレイティッドフィンは椆井の流れに乱れ を生じさせ，伝熱特性を改善させる特徵を有する.

流れ場の測定には直径 $5 \mu \mathrm{m}$ のタングステン線を センサとする I 型熱線プローブと定温度形熱線流速 計を使用した．管群後流の測定では，流れ場への影 響を最小限に抑えるために，図 1 に示寸ように主流

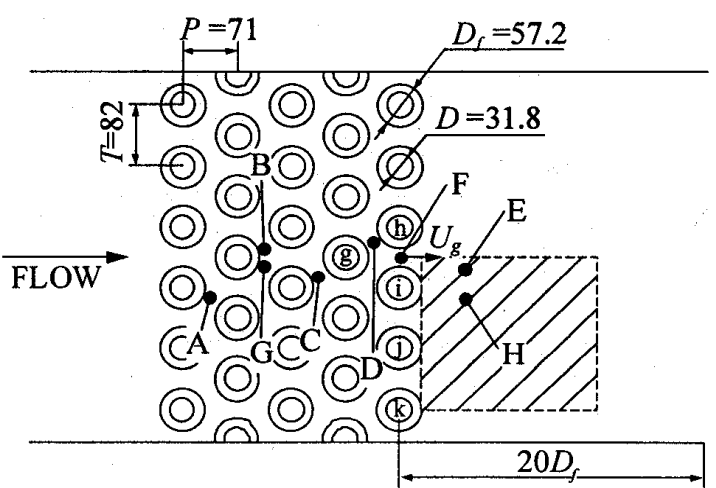

Fig. 2 Arrangement and dimensions of the tube and test section 
に平行に直径 $4.7 \mathrm{~mm}$ のプローブを下流から挿入し た. 熱線は渦放出に因る速度变動を測定するために フィン付き管のスパン方向 $(Z$ 方向) に平行に張ら れており, トラバース装置により流れ方向 $(X$ 方向 $)$ および流れに垂直方向（ $Y$ 方向）に $0.1 \mathrm{~mm}$ の刻みで 位置決めが可能である. 測定はダクト中央 $Z=0 \mathrm{~mm}$ の $X-Y$ 断面上で行った.

管群内の測定は, 側壁面より熱線プローブを $Y$ 軸 に平行に挿入して行った. 熱線は, 後流の測定同様, 管のスパン方向に平行である．熱線を管群内に挿入 した場合，測定部断面におけるプローブの閉塞率は 0.0047 と小さいことから，管群全体の系に及ぼすプ ローブ挿入の影響は無視できると考えている. ギャ ップ流速 $U_{g}$ は図 2 の最後列の管間中央の点 $\mathrm{F}$ に下 流側から熱線を挿入し測定した值を用いた.この流 速は，連続の式を考慮すると管群一列目から最後列 目でほぼ等しくなる．なお，工学的にはギャップ流 速として測定值よりもギャップ間の平均流速を用い る方が一般的である。これについては今後検討する 予定である。

速度変動特性として, 平均流速, 速度変動強さ $u$, 速度変動のスペクトル，コヒーレンス，位相差を測 定した. なお，速度変動のスペクトルの縦軸は変動 の振幅値を表している， $u^{\prime}$ は，速度変動の標淮偏差 を主流速度 $U_{\infty}$ で除した值として定義する．測定で は 0.1 秒間の速度変動の実効值を 300 回平均化処理 した. 速度変動のスペクトル, 相互相関係数, コヒ ーレンスは $500 \mathrm{~Hz}$ レンジにて 48 回の平均化処理を 行った.

\section{4. 実験結果および考察}

4-1 フィン付き管の等価直径 著者らの単管

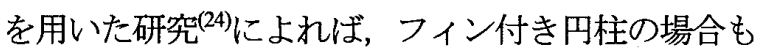

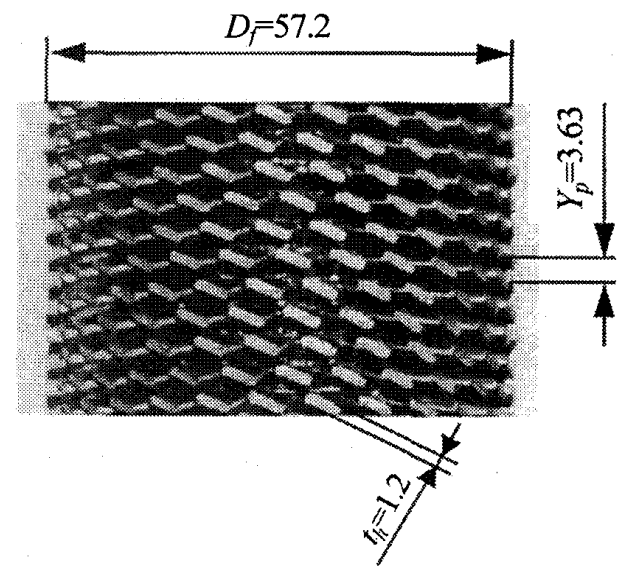

Fig. 3 Shape of a tube with twist serrated fin $\left(Y_{p}=3.63 \mathrm{~mm}\right)$
カルマン渦が放出され，フィンはちょうど円柱直径 が増加するのと同様の効果を有する．そこで著者ら は円柱にフィンを設置した場合の円柱径の目安の寸 法をフィン付き管の幾何学的条件を用いて，次式で 定義して等価直径 $D^{*}$ と名付けた ${ }^{(24)}$.

$$
D^{*}=D+\frac{\left(D_{f}-D\right) t_{h}}{Y_{p}}
$$

単独円柱に $Y_{p}=3.63 \mathrm{~mm}$ のツイストセレイティッド フィンを設置した場合，フィン先端のひ称りを考慮 してフィンの厚さ $t_{h}$ を最大厚さ $2.9 \mathrm{~mm}$ と考える と, 等価直径 $D^{*}$ は $52.1 \mathrm{~mm}$ となる.

4.2 管群内の流れ場 図 4(a) 〜 (d) はギヤ ップ流速 $U_{\mathrm{g}}$ が $28.0 \mathrm{~m} / \mathrm{s}$ のときの管群内の各列直後の 速度変動の強い場所における速度変動のスペクトル である. 測定点は図 2 の点 A D に対応している.

図 4 (a) 〜 (d) にはそれぞれ $171.25 \mathrm{~Hz}$ のピークが 形成されており，管群内では単一の周波数の周期性 の強い速度変動が生じていることがわかる.

この周期性の強い現象の特性を調べるため，管群 内二列目後方の点 $\mathrm{B}$ に熱線を挿入し，ギャップ流速 $U_{g}$ を変化させて速度変動のスペクトルを測定した. ギャップ流速 $U_{g}$ に対するスペクトルのピーク周波 数 $f_{p}$ の変化を図 5 中下側に示寸. ピーク周波数 $f_{p}$ は ギャップ流速 $U_{g}$ に比例し増加するが, その勾配が流 速によって変化することがわかる. ギャップ流速 $U_{g}$ と等価直径 $D^{*}$ を用いたストローハル数 $S_{t}$ は, ギャ

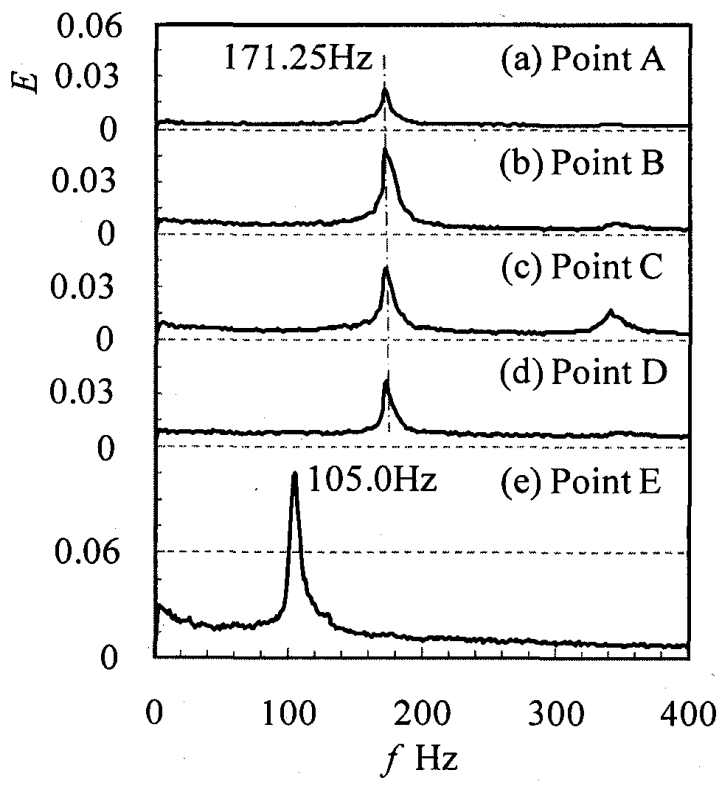

Fig. 4 Spectrum of velocity fluctuation at $u_{\max }^{\prime}$ point around tube banks $\left(U_{\mathrm{g}}=28.0 \mathrm{~m} / \mathrm{s}\right)$ 


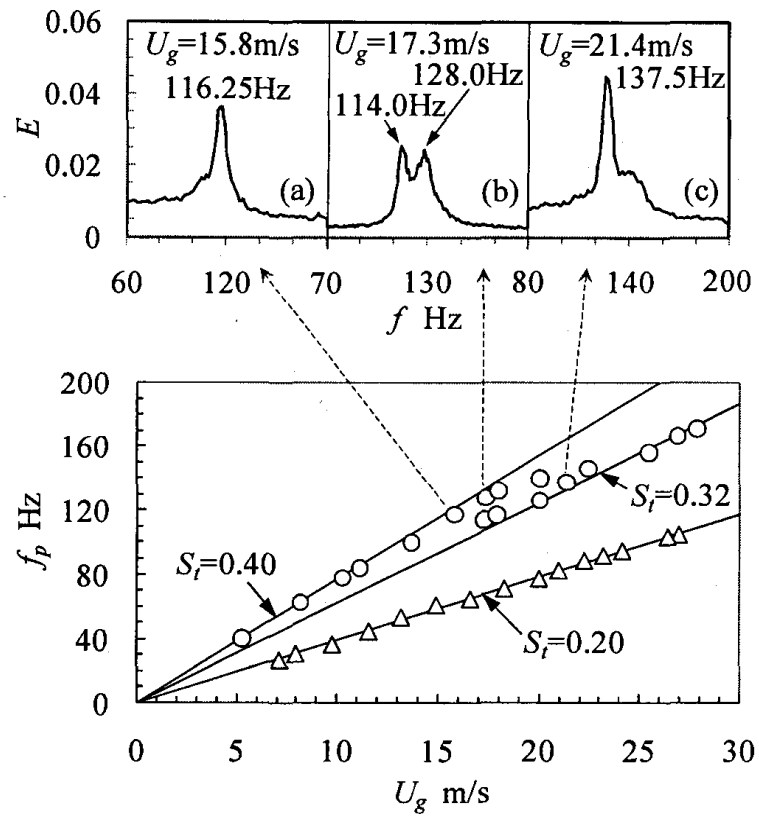

Fig. 5 Variation of peak frequency against the gap velocity at the point $B$

ップ流速が約 $16 \mathrm{~m} / \mathrm{s}$ 末満では約 0.40 となり, 約 $21 \mathrm{~m} / \mathrm{s}$ 以上では約 0.32 となる.これらの間の流速のスペク トルを図 5 中上側 (a) 〜 (c) に示す. ギャップ流 速 $U_{g}$ が $15.8 \mathrm{~m} / \mathrm{s}$ では, 図 5 (a) のように $S_{l}=0.40$ 成 分の $116.25 \mathrm{~Hz}$ の卓越した単一のピークが形成され るが，これより流速が大きくなると図 5 (b) に示す ように $114.0 \mathrm{~Hz}$ ( $S_{i}=0.32$ 成分) が現れ, $128.0 \mathrm{~Hz}\left(S_{l}=0.40\right.$ 成分）との二つのピークを有する双峰性の分布とな る. さらに流速が増加すると, $S_{l}=0.40$ 成分の高周波 側のピークレベルが徐々に低下し, 一方 $S_{l}=0.32$ 成分 の低周波側のピークレベルが増加して，ギャップ流 速が $21.4 \mathrm{~m} / \mathrm{s}$ では図 5 (c) に示すように $S_{i}=0.32$ 成分 の $137.5 \mathrm{~Hz}$ の単一のピークのみとなる.

次にこの周期性の強い現象の原因を調べるため, 管群二列目の管後方の図 2 に示す点 $\mathrm{B}$ と点 $\mathrm{G}$ に 2 本の熱線をそれぞれ反対側のダクト側壁より挿入し， 速度変動の位相差を測定した. 図 6 (a) と（b）は ギャップ流速がそれぞれ $14.0 \mathrm{~m} / \mathrm{s}$ と $20.0 \mathrm{~m} / \mathrm{s}$ の結果で ある. 管後方の対称な 2 点間の速度変動の位相差が スペクトルのピーク周波数 $101.25 \mathrm{~Hz} \quad\left(S_{l}=0.40\right.$ 成分） と $127.5 \mathrm{~Hz}$ ( $S_{t}=0.32$ 成分) ではどちらも約 $180^{\circ}$ と なる.これは, 一本の管の後流の二つの速度変動は 一方が大きいとき, 他方が小さくなり，互いに逆位 相であることを表している.

次に，管群内の速度変動のスペクトルが図 5 (b) に示されるように双峰性を成す原因を調べるため, ギャップ流速 $U_{\mathrm{g}}=17.3 \mathrm{~m} / \mathrm{s}$ において測定した速度変

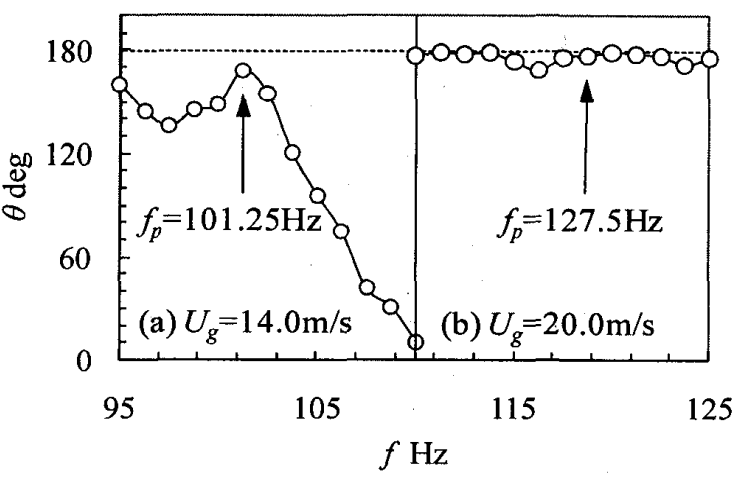

Fig. 6 Phase delay between velocity fluctuations downstream of the second row of tube banks

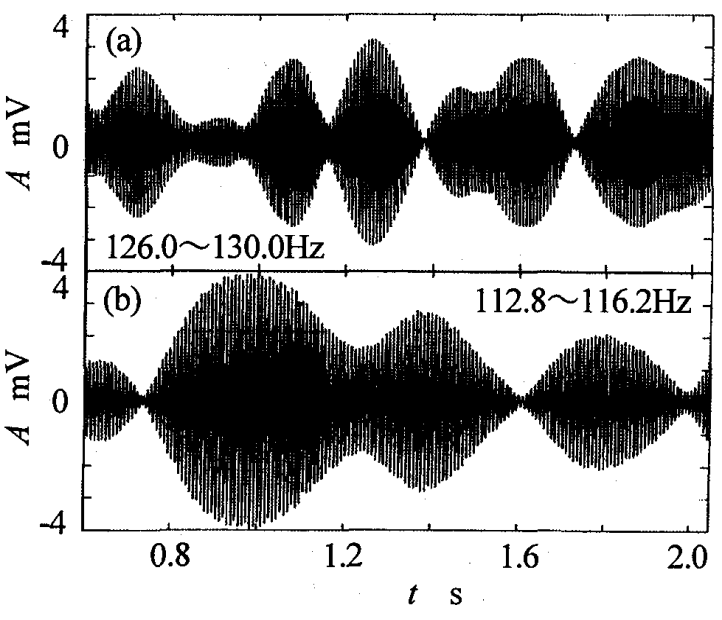

Fig. 7 Time variation of amplitude of two peak frequency components $\left(U_{\mathrm{g}}=17.3 \mathrm{~m} / \mathrm{s}\right)$

動の時系列データから，バンドパスフィルターを用 いて $f=126.0 \sim 130.0 \mathrm{~Hz}$ と $f=112.8 \sim 116.2 \mathrm{~Hz}$ の二つの 帯域の速度変動成分を分離し，振幅の時間変化を同 時刻にて比較した. 図 7 (a) は $126.0 \sim 130.0 \mathrm{~Hz}$ の周 波数帯域の速度変動成分, (b) は $112.8 \sim 116.2 \mathrm{~Hz}$ の成分に対する結果で，横軸は時間，縦軸は熱線出 力值である.これらの波形を比較すると，図7 (a) と（b）は一方の波形の振幅が大となるとき，もう一 方の振幅が小となる。このことから二つの周期現象 は時間的に同時に発生しているのではなく，一方が 発生すると他方は消滅の傾向にあることがわかる. このことと，管後方の速度変動の位相が $180^{\circ}$ ずれ ていること，ギャップ流速によってストローハル数 が変化するが，局所的にはピーク周波数がギャップ 流速に比例し増加することを考慮すると，これらの 周期性の強い現象はカルマン渦放出に因ると考えら れる. 流速によってストローハル数が変化する原因 


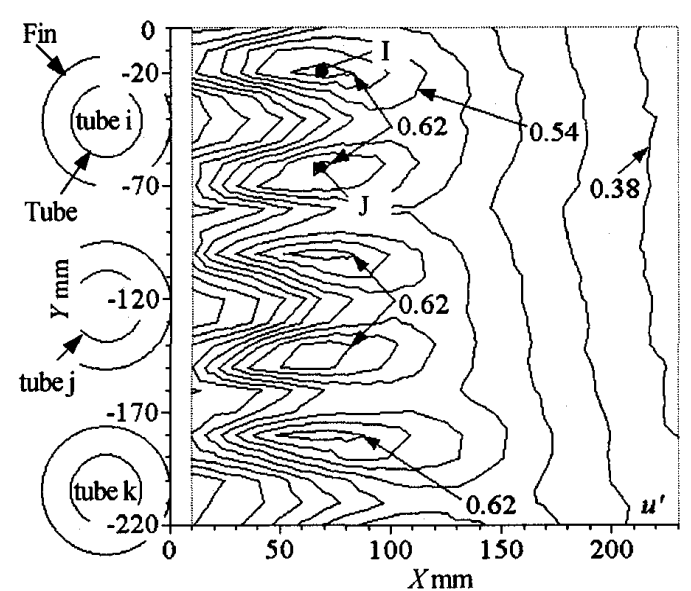

Fig. 8 Characteristics of velocity fluctuation in the wake of the tube banks with serrated fin $\left(U_{g}=20.0 \mathrm{~m} / \mathrm{s}\right)$

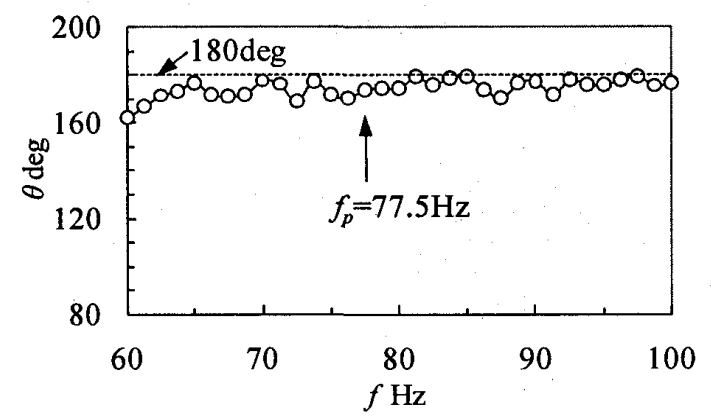

Fig. 9 Phase delay between velocity fluctuations downstream the second row of tube banks $\left(U_{g}=20.0 \mathrm{~m} / \mathrm{s}\right)$

は, フィン間の流れが変化してフィン付き管の渦放 出に関する代表寸法が増加したためであると考えら れる.

以上のことからピッチが $3.63 \mathrm{~mm}$ のツイストセレ イティッドフィン付き管群内の管からもカルマン渦 が放出されていることが明らかである.

\section{3 管群後方の流れ場 図 8 はギャップ流速} $20.0 \mathrm{~m} / \mathrm{s}$ のときの管群後方の速度変動強さの等高線 図である. 測定領域は図 2 中に示寸陰影部である. 図 8 中左側にフィン付き管の位置と管の番号を表し ている.

速度変動強さはそれぞれの管の後方約 $1.2 D_{f}$ の二 つの点で最大となり，下流に向かうにつれて徐々に 低下している. ギャップ流速が $27.0 \mathrm{~m} / \mathrm{s}$ 時のこの速 度変動強さ最大点（図 2 中の点 $\mathrm{E}$ ) のスペクトル分 布を図 4 (e) に示す. $105.0 \mathrm{~Hz}$ に単一の卓越したピ 一クが見られるが，管群内と比ベレベルが高く，管

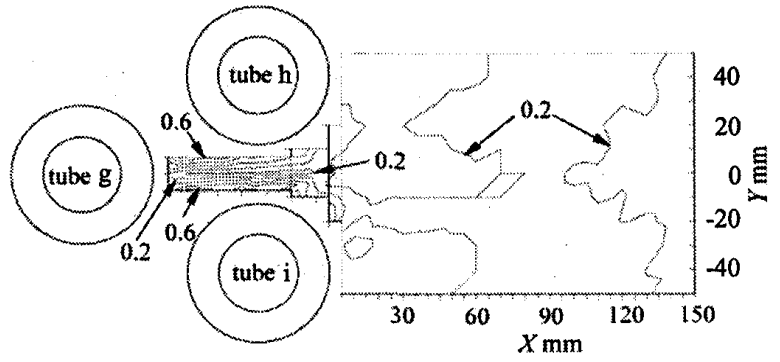

(a) Partial overall level about $156.25 \mathrm{~Hz}$

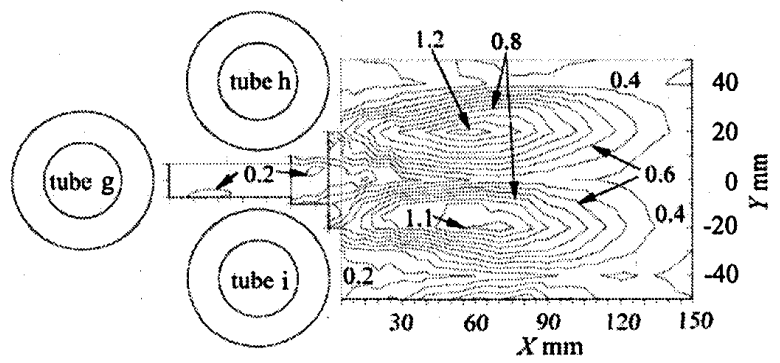

(b) Partial overall level about $97.5 \mathrm{~Hz}$

Fig. 10 Contour map of partial overall value around the last row of the tube banks $\left(U_{g}=25.4 \mathrm{~m} / \mathrm{s}\right)$

群後流では極めて強い速度変動が生じていることが わかる.

この速度変動の発生原因を調べるため, 速度変動 強さ最大点（図 8 中の点 $\mathrm{I}, \mathrm{J}$ ) に熱線を挿入し，2 点間の速度変動の位相差を測定した. ギャップ流速 $20.0 \mathrm{~m} / \mathrm{s}$ のときの結果を図 9 に示す. 管後方の対称な 2 点間の速度変動の位相差がスペクトルのピーク周 波数 $77.5 \mathrm{~Hz}$ において約 $180^{\circ}$ となることから，互い に逆位相であることがわかる.

図 5 中の $\triangle \mathrm{E}$ 印は, 図 2 中の点 $\mathrm{E}$ で測定した速度変 動のピーク周波数を示したものである. 管群内とは 異なりギャップ流速 $U_{g}$ が増加するにつれてピーク 周波数 $f_{p}$ が直線的に増加することがわかる. このこ とと, 最後列の管の後方に二つの速度変動強さの最 大点が存在すること, 速度変動のスペクトルに卓越 したピークが形成されることを考慮すると，管群後 流にも管群内と同様に周期性の強いカルマン渦が形 成されていると考えられる. ギャップ流速 $U_{g}$ と等価 直径 $D$ をを用いたストロー八ル数 $S_{1}$ は 0.20 となる.

以上のことから，フィン付き管群の後流にもカル マン渦が形成されるが，その速度変動強さと周期性 は管群内と比べ強くなることがわかった.

4.4 管群内と後流の渦の関係 管群内と管群 後流の渦のストローハル数が異なることから，これ らの二つの渦の関連性を調べるため, 管群内と管群 後流の境界に位置する最後列管近傍の流れ場の速度 
変動のスペクトルを測定した. 図 10 は, スペクトル の二つのピークに着目し，それぞれのピーク周波数 から $-5 \sim+5 \mathrm{~Hz}$ の周波数帯域に入る変動の強さを 表すパーシャルオーバオ一ル值の等高線図である.

值が大きいほど変動が強いことを表している.

図 10 (a) はギャップ流速 $U_{g}=25.4 \mathrm{~m} / \mathrm{s}$ における $156.25 \mathrm{~Hz}\left(S_{F}=0.32\right)$ 成分の結果である. この成分は 主として管群の最後列近傍に分布しており，管群下 流では急激に小さくなることがわかる.

図 10 (b) は $97.5 \mathrm{~Hz}\left(S_{i}=0.20\right)$ 成分の結果である. $S_{i}=0.32$ 成分とは傾向が異なり，管群近傍では小さく, 管群の下流約 $1.2 D_{f}$ 周辺で大きくなる，なお，図は 省略するが, ギャップ流速 $U_{g}=14.0 \mathrm{~m} / \mathrm{s}$ において管群 内の $S_{i}=0.40$ 成分と管群後流の $S_{i}=0.20$ 成分とを比較 した場合にも同様の結果が得られた.

以上のことから，管群内で生じているストローハ 儿数 $S_{i}=0.40$ と $S_{l}=0.32$ の速度变動成分は管群功下 流へ離れるにつれて減衰し, 逆に管群後流では, $S_{i}=0.20$ 成分の速度変動成分が誘起されていると考 えられる.この傾向は前報(25)のピッチが $5.08 \mathrm{~mm} の$ 場合と同じである，なお，管群内の渦のストロー八

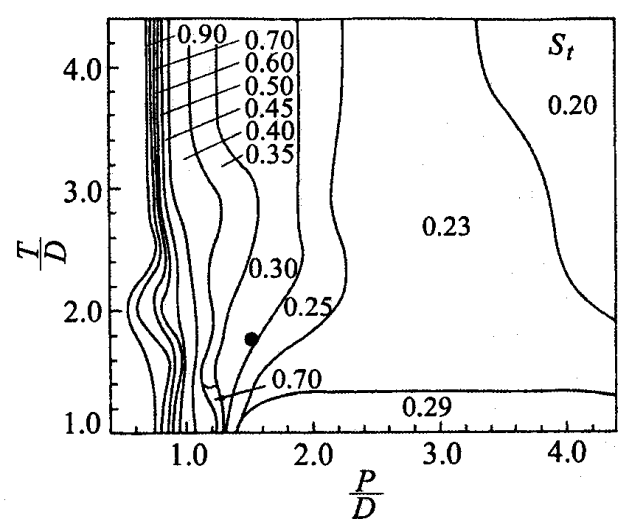

Fig. 11 Fitz-hugh's Strouhal number map

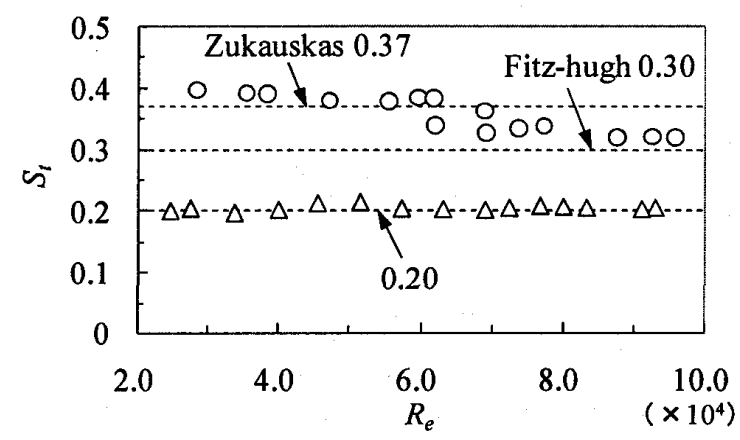

Fig. 12 Comparison between Strouhal number using equivalent diameter and the value read from Strouhal number maps.
ル数が流速によって変化するにもかかかわらず，後流 の渦のストローハル数が 0.20 で一定となる原因は, ピッチが $5.08 \mathrm{~mm}$ の場合と同様に管群内と後流の渦 とはお互いに相関がなく，管群内の渦の周波数が後 流の渦の周波数に影響しないためであると考えられ $ろ^{(25)}$.

以上の検討結果から，管群内では流速によってス トローハル数 0.32 と 0.40 の渦が, 管群後流では 0.20 の渦が放出されていることがわかった.

4.5 等価直径の検証 ここでは，著者らが提 案した等価直径の算定法 ${ }^{(24)(25)}$ が，ピッチが $3.63 \mathrm{~mm}$ のフィン付き管群に対して適用できるかどうかにつ いて検討する。

図 11 に裸管を用いた管群内の放出渦現象に対し て広く引用されている Fitz-hugh のストローハル数 のマップ(8)を示す。縦軸が揚力方向のピッチ比 $T / D$, 横軸が抗力方向のピッチ比 $P / D$ である. 管群から放 出される渦のストローハル数は, 管直径 $D$ を代表寸 法とし，管ギャップ流速 $U_{g}$ を代表速度として定義さ れている。

管直径 $D$ として前述の $D^{*}=52.1 \mathrm{~mm}$ を用いると, 図 2 に示される本実験の仕様から $T / D^{*}=1.57$ および $P / D^{*}=1.36$ となる. 図 11 中のの印はこの座標を示し ており, 図から読んだストローハル数 $S_{t}$ は約 0.30 と なる.

図 12 に, 等価直径と, 本実験で得た周波数および 実測したギャップ流速を用いて算出したストロー八 ル数のレイノルズ数に対する変化を示す．渦放出周 波数として管群内のものを用いたストローハル数を

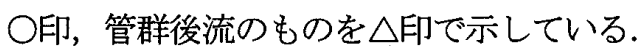

図 12 よりレイノルズ数が $6.2 \times 10^{4} \sim 9.6 \times 10^{4}$ にお いて管群内の渦の低周波側のストローハル数 0.32 之 破線で示した Fitz-hugh のマップから読んだストロ 一八ル数 0.30 とがほぼ一致していることがわかる. したがって，レイノルズ数によっては著者らが提案 した等価直径の算定法 ${ }^{(24)(25)}$ が，ピッチが $3.63 \mathrm{~mm}$ の フィン付き管群に対しても有効であると考えられる。 しかしながら，レイノルズ数が $2.8 \times 10^{4} \sim 6.9 \times 10^{4}$ においては管群内の渦の高周波側のストローハル数 は約 0.40 となり, Fitz-hugh のマップから読んだス トローハル数 0.30 とは一致しなかった.

ところで，管群から放出される渦の周波数と種々 の管配列の関係は，ストローハル数の予測式として Y. N. Chen ${ }^{(5)}$, A. Zukauskas ${ }^{(9)}$, D. S. Weaver ${ }^{(10)}$, A. Oengören ら ${ }^{(11)}$ も明らかにしている. 図 11 之同様に して，これらのマップから值を読むと本配列の仕様 
ではそれぞれ $0.54,0.37,0.58,0.36$ と 0.52 となる. この中で, A. Zukauskas らの值 0.37 と A. Oengören らの 0.36 が, レイノルズ数が $2.8 \times 10^{4} \sim 6.9 \times 10^{4}$ に おける本管群内の高周波側のストローハル数約 0.40 とほぼ一致することがわかる。

予測式による結果の違いは，管群配列の分類の仕 方と適用範囲によって子測式の線の引き方が異なる こと，式の導出に用いられた複数の論文の実験結果 に若干のばらつきがあることなどが原因である。こ のばらつきは，渦放出周波数の同定に用いた実験装 置と測定方法，レイノルズ数，管群の本数と配列の 仕様の相違が主な原因であると考えられる。したが って, ストローハル数の予測精度を向上させるには， 複数のマップや予測式を併用した方が良い。これら を考慮すると，著者らが提案したフィン付き管の等 価直径の算定法 ${ }^{(24)(25) か ゙ ， ヒ ゚ ッ チ か ゙ ~} 3.63 \mathrm{~mm}$ のフィン 付き管群に詨しても有効であると考えられる. しか しながら,図 12 中の $\triangle$ 印に示すように管群後流の渦 の周波数を用いたストローハル数は約 0.20 となり， これらのマップや式とは一致しなかった。

ところで，著者らはピッチが $5.08 \mathrm{~mm}$ のフィン付 き管群において，ギャップ流速と等価直径を用いて 算定した管群後流の渦のストローハル数が約 0.18〜 0.2 となり ${ }^{(25)}$, 単独円柱後流の渦のストローハル数 $0.2^{(26)}$ とほぼ一致することを明らかにしている.ピッ チが $3.63 \mathrm{~mm}$ の本結果も同様であることから，本フ イン付き管群の場合にも管群後流の渦の放出周波数 は，裸管からの渦放出周波数と同様に見積もること が出来ると考えられる.

\section{5. 結 論}

ピッチが $3.63 \mathrm{~mm}$ のセレイティッドフィン付き管 群からの渦放出特性を実験的に調査し，等価值径の 千鳥配列管群への適用性を検討した. その結果, 以 下の結論を得た。

（1）管群内の渦の周波数はギャップ流速に比例し增 加するが，その勾配がレイノルズ数によって変化す る. ギャップ流速と等価直径を用いたストローハル 数は,レイノルズ数が $2.8 \times 10^{4} \sim 6.9 \times 10^{4}$ では約 0.40 となり, $6.2 \times 10^{4} \sim 9.6 \times 10^{4}$ では約 0.32 となる. レ イノルズ数が $6.2 \times 10^{4} \sim 6.9 \times 10^{4}$ では，これらの二 つの周期現象は時間的に同時に発生しているのでは なく, 一方が発生すると他方は消滅の傾向にある.

(2)フィン付き管を等価裸管モデルで置き換えた等 価直径と，管ギャップ流速を用いて無次元化したス トローハル数は, レイノルズ数が $6.2 \times 10^{4} \sim 9.6 \times 10^{4}$
では管群内で発生する渦の周波数が約 0.32 となり， Fitz-hugh の線図から得られる值とほぼ同じになる。 レイノルズ数が $2.8 \times 10^{4} \sim 6.9 \times 10^{4}$ では管群内の渦 のストローハル数は約 0.40 となり, A. Zukauskas と A. Oengören らの予測式から得られる值とほぼ同じ になる.

（3）管群後流で発生する渦の周波数を等価直径と管 ギャッブ流速を用いて無次元化したストローハル数 は約 0.20 となり，単独円柱後流の渦のストローハル 数とほぼ一致する.

\section{文 献}

(1) Païdoussis, M. P., A Review of Flow-induced Vibrations in Reactors and Reactor Components, $J$. Nuclear Eng. Design, 74, (1982), pp.31-60.

(2) Pettigrew, M. J., Taylor, C. E., Vibration Analysis of Shell-and Tube Heat Exchangers: An Overview-Part 1:Flow, Damping, Fluidelastic Instability, J. Fluids Struct., 18, (2003), pp.469-483.

(3) Pettigrew, M. J., Taylor, C. E., Vibration Analysis of Shell-and Tube Heat Exchangers: An Overview-Part2: Vibration Response, Fretting-wear, Guidelines, J. Fluids Struct., 18, (2003), pp.485-500.

(4) Owen, P. R., Buffeting Excitation of Boiler Tube Vibration, J. Mech. Eng. Sci., 7, (1965), pp.431-439.

(5) Chen, Y. N., Flow-induced Vibration and Noise in Tube-bank Heat Exchangers due to Von Karman Streets, Trans. ASME, J. Eng. Ind., Series B, Vol. 94, (1968), pp.134-146.

(6) Weaver, D. S., Vortex Shedding and Acoustic Resonance in Heat Exchanger Tube Arrays, In Technology for the 90's, ASME, (1993), pp.776-810.

(7) Ziada, S., Oengören, A., Vortex Shedding in an In-line Tube Bundle with Large Tube Spacings, $J$. Fluids Struct., 7, (1993), pp.661-687.

(8) Fitz-hugh, J. S., Proc. UKAEA/NPL Int. Symposium on Vibration Problems in Industry., (1973), Keswick, England, Paper 427, 1-17.

(9) Zukauskas, A., Katinas, V., Flow-indeced Vibration in Heat Exchanger Tube Banks, In Practical Experiences with Flow-induced Vibrations, (1980), pp.188-196.

(10) Weaver, D. S., Fitzpatrick, J. Á., ElKashlan, M., Strouhal Numbers for Heat Exchanger Tube Arrays in Cross Flow, ASME J. Pressure Vessel Technology. 109, (1987), pp.219-223

(11) Oengören, A., Ziada, S., An In-depth Study of Vortex Shedding, Acoustic Resonance and Turbulent Forces in Normal Triangle Tube Arrays, J. Fluids Struct., 12, (1998), pp.717-758.

(12) Suzuki, S., Ugai, Y., Maruta, Y., Mori, S., Noise Prevention in Tube-Type Heat Exchangers Employed in Gas Turbines, Trans. JSME, Vol. 52B, No. 477, (1986), pp.2137-2142.

(13) Nemoto, A., Yamada, M., Flow-induced Acoustic Resonance Caused by Fin-tube Bundles, Symposium on Flow-induced Vibration and Noise, ASME PVP-Vol. 243, Vol.4, (1992), pp.137-152.

(14) Nemoto, A., Takakuwa, A., Tsutsui, M., Flow-induced Acoustic Resonance with Various Finned Tube Banks, Flow-induced Vibration and Noise, ASME, Vol.2, AD-Vol.53-2, (1997), pp.311-320. 
(15) Nemoto, A., Hara, F., Takakuwa, A., Tsutsui, M., Flow-Induced Acoustic Noise in Staggered Tube Banks, Trans. JSME, Vol. 65C, No. 635, (1999), pp.129-135.

(16) Mair, W. A., Jones, P. D. F., Palmer, R. K. W., Vortex Shedding from Finned Tubes, J. Sound Vib., Vol.39, No.3, (1975),pp.293-296.

(17) Kouba, J., Vortex Shedding and Acoustic Emission in Finned Tube Banks Exposed to Cross Flow, ASME Pressure Vessels and Piping Conference, Vol.104, (1983), pp.213-217.

(18) Kawaguchi, K., Okui, K., Kawabe, Y., Vortex Generation Characteristics of Serrated Finned Tube Banks with Staggered Arrangement (1st Report: Classification by the Frequency of Vortex Generation), Turbomachinery, Vol. 31, No. 3, (2003), pp.181-189.

(19) Kawaguchi, K., Okui, K., Kawabe, Y., Vortex Generation Characteristics of Serrated Finned Tube Banks with Staggered Arrangement (2nd Report: Effects of Tube Diameter and Fin Height), Turbomachinery, Vol. 31, No. 4, (2003), pp.227-236.

(20) Okui, K., Kawaguchi, K., Kawabe, Y., Vortex Generation Characteristics of Serrated Finned Tube Banks with Staggered Arrangement (3rd Report: Study on Reduction Method of Vortex Generation), Turbomachinery, Vol. 31, No. 6, (2003), pp.330-337.
(21) Hirota, K., Nakamura, T., Kikuchi, H., Isozaki, K., Kawahara, H., Fluidelastic and Vortex Induced Vibration of a Finned Tube Array, Dynamics and Design Conference 2001, No.621, (2001), CD-ROM

(22) Ziada, S., Jebodhsingh, D., Weaver, D. S., Eisinger, F. L., The Effect of Fins on Vortex Shedding from a Cylinder in Cross-flow, J. Fluids Struct., 21, (2005), pp.689-705.

(23) Hamakawa, H., Nakashima, K., Kudo, T., Nishida, E., Fukano, T., Vortex Shedding from a Circular Cylinder with Spiral Fin, J. Fluid Science and Technology, Vol.3, No. 6, (2008), pp.787-795.

(24) Hamakawa, H., Fukano, T., Aragaki, M., Nishida, E., Vortex Shedding from a Circular Cylinder with Fin, Trans. JSME, Vol. 65B, No. 635, (1999), pp.18-25.

(25) Hamakawa, H., Fukano, T., Nishida, E., Syoda, Y., Morooka, T., Vortex Shedding from Tube Banks with Serrated Fin, Trans. JSME, Vol. 66B, No. 646, (2000), pp.1301-1308.

(26) Roshko, A., On the Development of Turbulent Wakes from Vortex Streets, Caltech Theses and Dissertations, California Institute of Technology, (1952). 